\title{
The Temple Mount / Haram al-Sharif
}

The best view overlooking the Temple Mount (in Hebrew, Har Ha-Bayit), or the Haram al-Sharif (Noble Sanctuary), is either from the Mount of Olives to its east or from the Haas Promenade on the so-called Hill of Evil Counsel to its south. The raised platform, crowned by the golden cupola of the Dome of the Rock (Qubbat as-Sakhrah), as well as various monuments built throughout the 1,300 years of the city's Islamic rule, visually dominate the Old City (see figures 1 and 36). Its sheer size and solid appearance compensate for its inferior elevation in comparison to the Western Hill-today's Armenian, Jewish, and Christian Quarters, which are some twenty-five meters higher-thus still deserving of the term acropolis, usually a town's or city's most elevated ground. More so than any other monument in the city, new or old, contradictory impressions emanate from this place, blending a sense of sanctity, peace, and salvation with hatred, tension, and violence.

The hill on which the platform sits is traditionally identified with Mount Moriah (Genesis 22:2). According to the biblical narrative, David bought the property from Araunah the Jebusite and erected an altar (2 Samuel 24:16-25 and 1 Chronicles 21:15-22), which his son, Solomon, replaced with the First Temple (2 Chronicles 3:1). The same location is also associated with the Binding of Isaac (Psalm 24:3; Isaiah 2:3 and 30:29; and Zechariah 8:3). Tradition holds that the site of the Second Temple, built after the Babylonian exile, and the restored Herodian Temple were erected in exactly the same spot as the First Temple. Though ancient sanctuaries were often built in place of earlier holy sites or monuments, even as divinities were substituted or religions replaced, no physical traces of either temple has survived, and thus speculations and opinions regarding the exact location are numerous and diverse. ${ }^{1}$ The choice to build the Dome of the Rock on the assumed spot of the 




FIGURE 36. Aerial view of the Haram al-Sharif, looking east. Photo by Hanan Isachar.

destroyed Jewish Temple, however, is documented in historical sources from the early Islamic period. ${ }^{2}$ Subsequently, the same site has been venerated by Muslims as the location of the "Farthest Mosque" mentioned in the Qur'an (17:1), marking the place of Muhammad's miraculous Night Journey to heaven (Surah al-Isra). In Muslim tradition, it was Ishmael, the ancestor of the Arab people, rather than Isaac, whom Abraham prepared to sacrifice (Qur'an 37:100-106).

For Jews, the location of the former temples has determined the direction of worship throughout the world from antiquity to the present. For Muslims, the original qiblah (direction of prayer) was toward the Haram al-Sharif; this was replaced by the Holy Kaaba in Mecca in the second year of the migration of the Prophet Muhammad to Medina, in 624 C.E. (Qur'an 2:142-44). ${ }^{3}$

Other than a few subterranean building components, consisting primarily of cisterns and water channels, many of which date to the Hellenistic period, the most substantial remainders of the enclosure wall can be linked to the renovations initiated under King Herod the Great in the second half of the first century B.C.E. and completed shortly before the outbreak of the First Jewish Revolt in 66 C.E. The most significant damage to the Herodian complex, in particular to the Jewish Temple and the Royal Stoa located on top of the platform, was suffered during the destruction caused by the Romans in the year 70 C.E. Whether, during the late Roman period, a pagan temple or simply a statue dedicated to Jupiter took the place 
of the former Jewish Temple is unclear. ${ }^{4}$ But it is generally agreed upon that, during Byzantine rule, there was a desire to eradicate the memory of the Jewish Temple and that the site was used as a quarry and garbage dump. ${ }^{5}$

The revival of the site as a major sanctuary occurred after the city's Muslim conquest in 638 C.E., first with the construction of a rudimentary mosque at the southern extremity of the platform and, most significantly, under Umayyad rule, with the building of the Dome of the Rock under Abd al-Malik in 691 C.E. and the al-Aqsa Mosque under his son Abd al-Walid in 715 C.E. ${ }^{6}$ Renovations and reconstructions, as well as numerous new building initiatives on top of the platform throughout the city's Islamic rule, testify to the important role the monument retained as an active place of worship, upholding its position as the third holiest pilgrimage site in Islam after Mecca and Medina. ${ }^{\text {? }}$

Though the destruction of the Herodian Temple in Jerusalem represents an important turning point in Jewish worship, not only eliminating the priesthood and animal sacrifice, but also affecting other significant religious, political, and cultural changes, the memory of the abolished ritual practice and vanished physical presence of the Temple has retained a central role in Judaism to this day. Sacred space in Herod's sanctuary was restricted to the Temple itself, including the various courtyards within the boundaries of the soreg (a low fence), thus segregating this area from most of the platform and enclosure wall, which remained accessible to Gentiles. After the destruction under the Roman general Titus in 70 C.E., the substructure gained sanctity, blurring the Temple's original barriers from the rest of the complex as early as the Roman and Byzantine periods. ${ }^{8}$

Throughout most of Islamic rule in the city, access to the platform itself was limited to Muslims. During the first few centuries of Ottoman rule, the policy of prohibiting non-Muslims from accessing the Haram was maintained, but the restriction was loosened in the early nineteenth century, when a few Westerners started to be permitted to visit and study the monument. During the Mandatory period, non-Muslims were officially granted access to the Haram for the first time, and the Ottoman Status Quo was extended to the Western Wall, allowing Jews to worship in this location. Under Hashemite rule, Jews were no longer able to enter East Jerusalem, but the platform remained accessible to Christian visitors and explorers.

Since the 1967 capture of East Jerusalem, Israel claimed political sovereignty over the compound, but granted the Waqf custodianship of the platform. ${ }^{9}$ The same Palestinian and Jordanian officials and clergymen who had administered the site before Israel's occupation continued to do so from Amman, with Israel's implicit consent. ${ }^{10}$ Though prayer has remained restricted to Muslims only-a rule imposed by the Israeli government, which is often challenged by religious and nationalistic Jewish fringe groups-access was opened to people of other faiths. ${ }^{11}$ Since then, regulations and disputes concerning the Temple Mount, including the 
platform and the Western Wall, have remained under the jurisdiction of the government and Israel's Supreme Court, requiring constant police and military surveillance. $^{12}$

Given the fact that the compound is not only considered a holy place but also an antiquities site, it falls under both the Preservation of the Holy Places Law of 1967 and the Antiquities Law of $1978 .{ }^{13}$ Since Israel's rule over East Jerusalem is contested, however, both locally by the Waqf and most of the region's Muslim and Palestinian population, as well as internationally, its authoritative bodies are frequently challenged and dismissed and many of its regulations are unenforceable. The most volatile interrelation among Israeli, Palestinian, and Jordanian authorities, and their dealings with extremist activist groups who view the compound as a symbol of their respective religious and national aspirations, impacts not only the daily rulings as they pertain to visitors and worshippers but also the physical maintenance of a historic key monument-one that requires constant attention and care.

The site of the Temple Mount / Haram al-Sharif therefore embodies a contradiction between a continued veneration transcending religious and national boundaries and the desire either to disrupt the memory of Jewish hegemony or to infringe on the religious freedom and legal entitlements of Muslim worshippers and administrators.

\section{EXCAVATIONS AND SURVEYS}

Architect Frederick Catherwood was the first Westerner known to have made detailed drawings of the Haram and the Dome of the Rock in 1833 (see figure 37). ${ }^{14}$ Between 1865 and 1869, Charles Wilson and Charles Warren conducted their survey of the complex, including numerous underground installations and various features of the enclosure wall. The results of their work, both the physical and published components, are still used as guidelines for archaeologists and researchers investigating the compound. ${ }^{15}$

The first important contributions to our knowledge of Islamic architecture and building chronology conducted during the last years of Ottoman rule are Keppel Archibald Cameron Creswell's studies of the Dome of the Rock and the al-Aqsa Mosque and Max van Berchem's collection of the Haram's Arabic inscriptions. ${ }^{16}$ Following the damage that was caused to the southern area of the platform during the earthquake of 1927, Robert Hamilton conducted a detailed investigation of the al-Aqsa Mosque and opened several excavation trenches within and near the building (see figure 38). ${ }^{17}$ Hamilton was at the time director of the British Mandate's Department of Antiquities and the work was thus conducted on behalf of the department, in coordination with the Waqf. His study of the mosque, including numerous plans, sections, and elevations, was published, but it unfortunately lacks 




FIGURE 37. Cross section of the Dome of the Rock (print after the first detailed drawings made by Frederick Catherwood in 1833 from Dehio and von Bezold, Die kirchliche Baukunst des Abendlandes, 1887, Pl. 10).

any detailed documentation of the excavated trenches, which exposed numerous fragments of mosaic floors. Whether their seemingly late Byzantine style points to the presence of an undocumented church on top of the platform, as was recently suggested-a thesis that would completely alter our understanding of the site during the years preceding the Muslim conquest-or whether they were from the early Umayyad mosque remains unresolved.$^{18}$ One could state, though, that Hamilton's venture was a rare and lost opportunity to properly document an excavation on top of the Haram.

The most extensive excavations to be carried out near the Temple Mount (Southern Temple Mount excavations), surrounding the southwestern corner of the enclosure wall and extending all the way to the southeastern corner, were initiated immediately after Israel's capture of East Jerusalem. Benjamin Mazar of Hebrew University directed the campaigns between 1967 and $1982 .{ }^{19}$ His work was continued under the supervision of Ronny Reich and Yaacob Billig and more recently under the directorship of Eilat Mazar. ${ }^{20}$ The latest discoveries are related to the so-called Herodian Street and Tunnel excavations on the Southeast Hill and encroach upon the area near the southern end of the Western Wall. ${ }^{21}$ Documented remains range in date between the Iron Age and the early Islamic period. The most significant structures uncovered include various Iron Age installations, building, and fortification walls; several Herodian-period access facilities to the platform from the south and the west, as well as cisterns and ritual pools from the same 




FIGURE 38. Plan of the Haram al-Sharif, with areas of excavation. Drawn by Franziska Lehmann.

period; Byzantine dwellings, workshops, and industrial installations; and, finally, a monumental Umayyad palace complex.

Another project initiated immediately after 1967 was the excavation along the western enclosure wall (Western Wall Tunnels excavations), constituting an extension of the work begun by several scholars of the PEF in the nineteenth century. ${ }^{22}$ Some of the early initiatives were supervised and published by archaeologist Meir Ben-Dov. He was replaced by Dan Bahat in 1985. ${ }^{23}$ Between 2007 and 2010, Alexander Onn continued the excavations on behalf of the IAA. ${ }^{24}$ The exposed remains, ranging in date between the late Hellenistic period and the modern era, are located within a strip, approximately one hundred meters long and eleven meters wide, 
which extends north of the Western Wall Plaza along the enclosure wall. Most significant are the remains of a Herodian-period arch bridge, sometimes referred to as the Great Causeway, beginning in the east, at Wilson's Arch and stretching westward across the Central Valley. Noteworthy among several buildings located in proximity to the bridge are the Masonic Hall from the Herodian period and the Madrassa al-Tankiziyya, built in 1329 and used as a courthouse during the Mamluk and Ottoman periods. ${ }^{25}$

In spite of the Haram's continued use as a religious sanctuary throughout the history of scientific exploration-and despite the fact that no comprehensive excavations have ever been conducted on top or under the platform-an astonishing amount of documentation has been assembled over the years that allows us to reliably reconstruct the history of this architectural complex, its various building sequences, alterations, destructions, and restorations. This understanding has helped us to trace not only the site's changing interrelationship with various surrounding buildings and access routes but also its impact on Jerusalem's urban profile as it evolved from antiquity to the present. Unlike the Southeast Hill, where conflicting chronologies and interpretations-to a large extent resulting from the use of biblical narratives as a reference to reconstruct cultural changes-still overwhelm the scholarship, very few controversies exist with regard to the structural history of the Temple Mount / Haram al-Sharif. No other monument in Jerusalem has been accompanied by such detailed and regular descriptions provided by contemporaries who visited or lived at the place or who were directly or indirectly involved in the changes that affected its physical appearance and its use.

Flavius Josephus provides us with two very detailed descriptions of Herod's construction of the Temple Mount complex. ${ }^{26}$ Early Christian and later medieval pilgrims documented first its use as a Muslim shrine, then its conversion into a Crusader stronghold, and then again back into a Muslim sanctuary. These accounts are complemented by numerous contemporary texts written by historians, geographers, theologians, and government officials. ${ }^{27}$ Inscriptions written in $\mathrm{He}-$ brew, Greek, Latin, and Arabic, most of them found in situ, as well as countless manuscripts stored over hundreds of years at the Haram, supplement the data that archaeologists, art historians, and historians have at their disposal. ${ }^{28}$ There are a few controversies surrounding some features of the site, but these are relatively minor. For example, there is a lack of support for the dating and interpretation of the so-called Solomonic Wall in the Southern Temple Mount excavations, there are the minor disagreements concerning the date of the renovations of the Herodian enclosure wall extensions and entrance routes and gates, and the dating of Ayyubid versus Crusader constructions are in dispute. These controversies, however, pale in comparison to the disputes that affect our understanding of the early history of the Southeast Hill. ${ }^{29}$ The clashes surrounding the Temple Mount or the Haram al-Sharif are indeed of a completely different nature. 


\section{CONSTRUCTION, DESTRUCTION, AND SALVAGE}

CAMPAIGNS

Given the fact that the Haram has functioned continuously as an active place of worship, archaeological surveys and investigations have always been conducted under particularly difficult conditions. ${ }^{30}$ Before Israel's capture of East Jerusalem, there was repeated tension and occasional clashes between the guardians of the compound and scholars investigating the site. These problems, however, did not much affect the structural maintenance of the monument and the relationship among the various institutional representatives involved in it. Any conflicts or tensions they had were relatively minor.

Beginning in 1967, however, with the major physical alterations-involving destruction, construction, and excavation-affecting the Haram compound and its immediate surroundings, the conflicts between the different religious and national groups took on new forms. This made it difficult, if not impossible, to undertake any kind of scientific investigation without impacting the highly sensitive and easily explosive nature of the political situation. Two initiatives immediately following the 1967 war set the stage for how Israel's transformation of the Haram's surrounding landscape would permanently alter not only the physical nature of the site but also the sociopolitical interactions among all involved religious groups who share an interest in the monument. The first was the destruction of the historic Mughrabi Quarter for the purpose of creating the Western Wall Plaza; the second was the continued large-scale excavation conducted along the southern and western enclosure walls. Despite the different nature of these actions, both efforts have been at the root of recurrent tensions between Israelis and Palestinians, often escalating from demonstrations and protests to violence and death, with regional as well as international repercussions.

The spatial modifications made by those two initiatives invited the Jewish and Israeli public to participate in this urban transformation in different dimensionsculturally, by experiencing the exposed antiquities within the context of the archaeological park; religiously, by visiting and praying at the Western Wall; and, finally, politically, by observing or partaking in IDF induction ceremonies on the plaza as well as other commemorations and ceremonies, often in the presence of Israel's president. ${ }^{31}$ Palestinian Muslims, in contrast, perceived these initiatives as aggressive and explicit attempts to undermine their religious, historical, and cultural ties with one of Islam's holiest sites-a site that had been under their exclusive governance for nearly 1,400 years-as well as the first irreversible steps toward physically encroaching upon or destroying some or even all of the complex.

Surprisingly, however, despite the general discontent within the Muslim world regarding the physical transformations around the Haram area, and notwithstanding the numerous conflicts and even violent clashes between Israelis and Palestinians around issues directly related to the governance and use of the compound, 
during the first three decades of Israeli occupation in East Jerusalem, there was some degree of cooperation among the various administrative bodies concerned with the site's archaeological and conservation efforts. ${ }^{32}$ Both the First Intifada, which broke out in December 1987, and the al-Aqsa Massacre of October 1990, referred to as the stormiest event in the history of Palestinian-Israeli violence at the compound, had already turned the sacred esplanade into a central locus of the national conflict. ${ }^{33}$ It was not until 1996 that the informal contacts between the Waqf and the IAA, which had existed since 1967, came to an end. The three key events that most significantly impacted this change were Prime Minister Netanyahu's decision to open the northern end of the Western Wall Tunnels in 1996; the construction of the Marwani Mosque, between 1996 and 1999; and, finally, Likud Party leader Ariel Sharon's visit to the Temple Mount in 2000. The first and third events were perceived by Palestinians as reinforcing the Jewish claim to the Temple Mount and more generally to the city of Jerusalem; the second, in contrast, was perceived by Israelis as an expression of Palestinian denial of Israel's sovereignty over the Haram and East Jerusalem. Since then, as a result of the heightened political tensions between Israelis and Palestinians, combined with the increased awareness, locally and internationally, that archaeology is being used as a political tool, the IAA has reiterated their classification of all new and all continued archaeological projects near the Haram as salvage work. In other words, rather than being conducted purely for the sake of exploring a site's archaeological and historical sequence for the purpose of knowledge construction-as could be easily argued in the case of the Southern Temple Mount excavations-all projects initiated after 1996 have been elaborately justified and broadly publicized by the IAA as necessary prerequisites for required maintenance, repair, or development work.

The opening of the northern end of the Western Wall Tunnels in 1996 led to a chain of catastrophic events and was likely the turning point that led to the IAA applying more scientifically and methodologically conscientious professional procedures and using more carefully designed public communication. Understood by Palestinians as an intentional and provocative act, meant not only to create a physical link between the Jewish and Muslim Quarters but also to encroach upon and potentially destroy a Muslim holy site, the opening of the tunnel led to several outbursts of protest. More publicly than ever, various Israeli governmental agencies-Netanyahu's Likud Party, the Western Wall Heritage Foundation, and the IAA - appeared to conflate political and archaeological interests. This intensified the perceived dual insult of deception and provocation. Verbal condemnations by Palestinian Muslims eventually evolved into gun battles, first in East Jerusalem and then spreading to the West Bank and Gaza Strip, killing a total of fifty-seven Palestinians and fifteen Israelis. ${ }^{34}$ The Palestinian activities in reaction to the opening of the Western Wall Tunnels are commonly referred to as the "al-Aqsa Intifada," highlighting the significant role archaeology and religion have 
played in the popular uprising against Israel's occupation. Following these fatal clashes, the Islamic Movement in Israel organized the first convention (mihrajan) under the banner "al-Aqsa is in danger," informing the Palestinian public that Israeli excavations constitute a physical threat to the al-Aqsa Mosque and that Israel is seeking, in a deliberate and systematic manner, to destroy the mosque in order to build the Third Temple in its place. ${ }^{35}$ Though excavations had never been carried out with the goal of physically undermining the compound, several Jewish fringe groups have repeatedly called for plans and initiatives to destroy the al-Aqsa Mosque and replace it with a Third Temple, which has contributed to this misunderstanding and the escalating fear among Muslims. ${ }^{36}$

Directly linked to the Western Wall Tunnels through a recently built underground passage and also administered by the Western Wall Heritage Foundation is the Ohel Yitzhak Synagogue, originally established in 1904, abandoned in the 1936-39 Arab revolt, and destroyed during the 1948 war. ${ }^{37}$ In conjunction with the renovations and reconstruction of the synagogue, which opened in 2008, excavations were conducted on the ground between 2004 and 2005, directed by Hervé Barbé and Tawfik De'adle from the IAA. Other than providing valuable information on the Roman and Byzantine street network, a well-preserved hammam (public bath house) from the Mamluk period, which was identified as Mustahamm Daraj al-Ayn, was exposed. ${ }^{38}$ This project establishes the unabashed and continued commitment of the IAA to conduct archaeological work adjacent to the Haram while ignoring Muslim sensitivities and fears about their restricted access to their holy site and their constrained ability to worship.

A further recent project claiming to prepare a necessary development initiative is the Western Wall Plaza excavations. The planned development concerns the Beit Haliba Building, designed to oversee prayer and tourism on the plaza and in the Western Wall Tunnels, as well as to provide office and conference space for the Western Wall Heritage Foundation. The salvage excavation, conducted between 2005 and 2009, was directed by Shlomit Weksler-Bdolah and Alexander Onn of the IAA and is located in the northwestern part of the prayer plaza, at about one hundred meters distance from the enclosure wall. Significant structural remains include an Iron Age dwelling of the four-room type (seventh century B.C.E.), a section of the colonnaded eastern Cardo from the Roman and Byzantine periods, a late Islamic building decorated with a unique ablaq-style fresco and equipped with a bakery (thirteenth to fifteenth centuries), and finally a late Ottoman building with a mihrab (nineteenth to twentieth centuries). It is noteworthy that the archaeological documentation includes reference to the layers of the recent 1967 destruction of the Mughrabi Quarter initiated to establish the Western Wall Plaza. ${ }^{39}$ The delay in the construction of the new building is a result of protests by the public and legal complaints filed by Israeli archaeologists. Criticism concerns the fact that the Beit Haliba Building will transform the current landsape of the Old 
City. As is the case with most other ambitious development efforts connected to archaeology and tourism in East Jerusalem, the building is considered a necessity exclusively from the viewpoint of Israel's occupation policy.

The most recent controversial excavation in East Jerusalem, initiated in 2007, is located near the Mughrabi Gate, the only access to the Haram used by nonMuslims (see figure 39)..$^{\circ}$ According to a public statement issued by the IAA on the Israel Ministry of Foreign Affairs website on February 12, 2007, the motivations for conducting the excavations were in the interest of all involved parties-Israelis, Palestinians, as well as foreign visitors to the Temple Mount. ${ }^{41}$

The collapse of the ramp [in 2004] posed a danger to tourists ascending to the Temple Mount and to the worshippers in the Women's Area in the Western Wall plaza below. The site was declared hazardous by the City Engineer immediately after the collapse. Greater Jerusalem, in its entirety, is a declared antiquities site. According to the Antiquities Law, the Israel Antiquities Authority is required to excavate every archeological site that has been damaged, willfully or by natural causes, so that any engineering plan (construction of a new bridge or strengthening of the existing ramp) requires a full archeological salvage excavation. The strengthening of the existing ramp or the construction of a new bridge necessitates construction of engineering infrastructures which in turn require a full archeological excavation. The importance of preserving the appearance of the Western Wall plaza as a holy site, dictates a suitable reconstruction of the damaged Mughrabi gate access. The new access should provide convenient and safe passage for visitors to the Temple Mount, including disabled persons.

Fully aware of the highly sensitive and inflammatory nature of the situation, the IAA proceeded in a most conscientious manner, publicizing that "professional work of the highest standard will be guaranteed." Committing to their "guiding principles" and "inter-religious considerations," IAA issued a declaration, which was also posted on the Israel Ministry of Foreign Affairs website.

The antiquities authority has never excavated, nor will it ever permit excavation, in the Temple Mount compound. It is a site of supreme historical value in which excavations are prohibited. All construction is to take place outside the Temple Mount, and care taken to preserve the status quo. The distance between the columns of the bridge and the Temple Mount will be $80 \mathrm{~m}$. The construction is being carried out in an area under Israeli sovereignty and under the responsibility of the Jerusalem $\mathrm{Mu}-$ nicipality and the Government of Israel. The parties responsible for religious affairs on the Temple Mount, including the Moslem Wakf, were kept informed of Israel's intention to restore the access, in the ongoing dialogue which exists between them. All care is taken that the construction of the new bridge does not harm religious sensitivities, the holy places, or other religious interests.

The continued overlap of Israel's occupation policies and their expanding investment in public archaeology and tourist sites in East Jerusalem, which have 


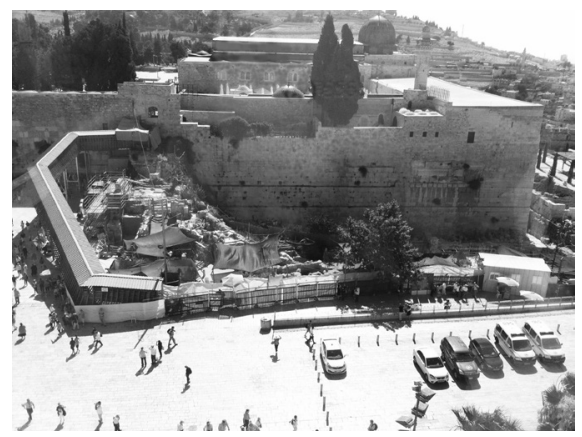

FIGURE 39. Mughrabi Gate ramp and excavations. Photo by Katharina Galor.

increasingly impinged on Palestinian entitlements to live in the city and claim a part in its historical and religious heritage, has completely blurred the lines between archaeological projects that are to the benefit of all religious and national communities and projects that are politically motivated. The painstaking nature of the planning procedures and the assurance to follow the highest professional standards have done little or nothing to quench the distrust of Palestinian residents, which is based on numerous prior so-called salvage excavations carried out in the occupied sector of the city.

Once again, the excavations were condemned, by both Hamas and Fatah, who called for Palestinians to unite in protest. Additional opposition was voiced by Jordan, Syria, Saudi Arabia, Malaysia, as well as the fifty-seven-member organization of the Islamic Conference, viewing these actions as a grave threat to one of Islam's three holiest mosques. Israel denied the charges and installed cameras to film the excavation, a further effort to be fully transparent in this endeavor. The footage was broadcast live on the web, which they hoped would ease the widespread anger. Despite the fact that UNESCO cleared the Israeli team of wrongdoing, confirming that no harm was being done to the Haram and that excavations were being carried out according to professional standards, their report recommended the cessation of the work. As a result of the local and international protest, the work was interrupted soon after it was launched, though it was resumed in 2013, to be completed in $2015 .{ }^{42}$

In response to the imposed political sovereignty and related archaeological activities touching upon the Haram compound, Palestinian efforts to physically claim the Muslim holy shrine culminated in the construction of the Marwani Mosque. Though widely covered in the local, mostly Israeli media, relatively little international attention was dedicated to this affair. Between 1996 and 1999, an ancient vaulted structure-which is popularly referred to as Solomon's Stables, though it is commonly dated to the Herodian period-located underneath the southeastern corner of the Haram platform, was converted into an underground 
mosque that can accommodate some ten thousand worshippers. The construction was officially carried out by the Islamic Waqf, with financial sponsorship and logistical assistance from the Islamic Movement in Israel under the stewardship of Shaykh Ra'id Salah, mayor of Umm al-Fahm-and leader of the movement's northern branch. A central tenet of the movement's activism within Israel has been its commitment to rehabilitate and restore holy places. It also champions the renovation of the al-Aqsa Mosque, popular protests against occupation, and the celebration of religious festivals at the compound. Other than refurbishing the underground vaulted structure, a new access ramp and staircase were built to facilitate entrance and egress. ${ }^{43}$ The clearing and construction process has been severely criticized by a group of Israeli archaeologists (who support continued occupation) for using bulldozers and for damaging and eliminating antiquities without proper archaeological supervision. ${ }^{44}$

On several occasions in 1999 and again in 2000, the construction material was dumped at various locations outside of the Old City. In 2000, archaeologists from the IAA began to examine the debris material for ancient artifacts. ${ }^{45}$ It was not until 2005, however, that the Temple Mount Sifting Project was formed, as a platform for Israeli archaeologists and activists dedicated both to protesting the construction inside a historic monument without archaeological supervision and to recovering additional artifacts from the dumps. ${ }^{46}$ After moving the discarded construction debris to the Tzurim Valley National Park, the material has been systematically sifted by Elad staff members, volunteers, and tourists. ${ }^{47}$

For the most part, religious and ideological perceptions and agendas with regard to the compound's historical legacy on the Jewish Israeli and the Palestinian Muslims fronts are thus either in support of occupation (for the former) or in reaction to occupation (for the latter). In response to the gradually increased scale of Israeli excavations at and near the Haram, beginning in 1967, and their growing public commitment to archaeological professional standards since the mid-199os, UNESCO's attempts to reprimand and Palestinian efforts to counter have been largely ineffective.

\section{ONE MONUMENT, TWO HERITAGE NARRATIVES}

The Temple Mount / Haram al-Sharif epitomizes the continuity of sacred space and represents a monument that transcends the change of religious affiliation and practice, having evolved from a Jewish sanctuary to a Muslim shrine-and temporarily into a Christian holy site along the way. But since Israel's occupation of East Jerusalem, it has turned into the city's main locus of religious and national tension, conflict, and repeated violence between Jews and Muslims, and more recently between Israelis and Palestinians, a situation that has impacted both the study and the preservation of a monument of shared value. 
For over a millennium, its primary use as a Muslim place of worship had not been challenged other than during Crusader rule. Throughout the early and late Islamic periods, the region's religiopolitical convergence assured the platform's unquestioned function as a Muslim place of prayer, study, and legal and civic activity. Jewish worship — relegated, for the most part, to the Western Wall-did not interfere or threaten its exclusive usage (see figure 40). The transfer of holiness from the Temple to its enclosure had occurred centuries before the Muslim conquest in 638 , having begun as a result of the destruction of the Jewish sanctuary by the Romans in 70 C.E. The first incidents of tension between Muslims and Jews did not occur until the British Mandate. These religious frictions were closely related to the emerging territorial conflict between Jews and Arabs, particularly heated in the context of shared holy places. Hostilities intensified during the period of Jordanian rule but were only rarely enacted on the grounds of the compound, mostly as a result of the Temple Mount's inaccessibility to Jews. A new chapter in the history of the compound and its role in the Israel-Palestine conflict began after Israel's capture of East Jerusalem, which placed all of the site's Muslim shrines and buildings under Israel's political authority, as well as police and military surveillance. Since 1996, the Temple Mount / Haram al-Sharif has indeed turned into the region's focal point, where the reciprocal traumas and violent expressions of Palestinian resistance to Israeli occupation have come to their fore in the most militant forms. The intense archaeological activity conducted by Israeli professionals, the lack of adequate archaeological supervision during construction and renovation initiatives by the Waqf authorities, and the absence of a coordinated plan for conservation and preservation efforts for the entire complex are the result of the site's deep implication in the Israel-Palestine conflict. Competing narratives of past traditions and current activities surrounding the Temple Mount / Haram al-Sharif have played a particularly powerful role in the increasingly violent clashes between Jews and Muslims, between Israelis and Palestinians.

One of the most controversial points of the compound is the Western Wall, a short section-about seventy meters-of the southern portion of the western enclosure wall, whose total length is 488 meters. Literary sources suggest that Jewish attachment to the Western Wall goes back to the tenth and eleventh centuries C.E., though there is a certain ambiguity regarding the exact location of that early attachment. ${ }^{4}$ The earliest Muslim tradition associating the Western Wall with alBuraq dates to the fourteenth century.49 It was not, however, till the rise of the Zionist movement in the early twentieth century that the wall became a source of significant friction between the Jewish and Muslim communities, leading to outbreaks of violence in 1928 and 1929 and the appointment of an international commission in 1930 by the British government to determine the rights and claims of Muslims and Jews in connection with the site..$^{50}$ The idea to purchase and demolish the adjacent Mughrabi Quarter to facilitate Jewish worship at the wall was 


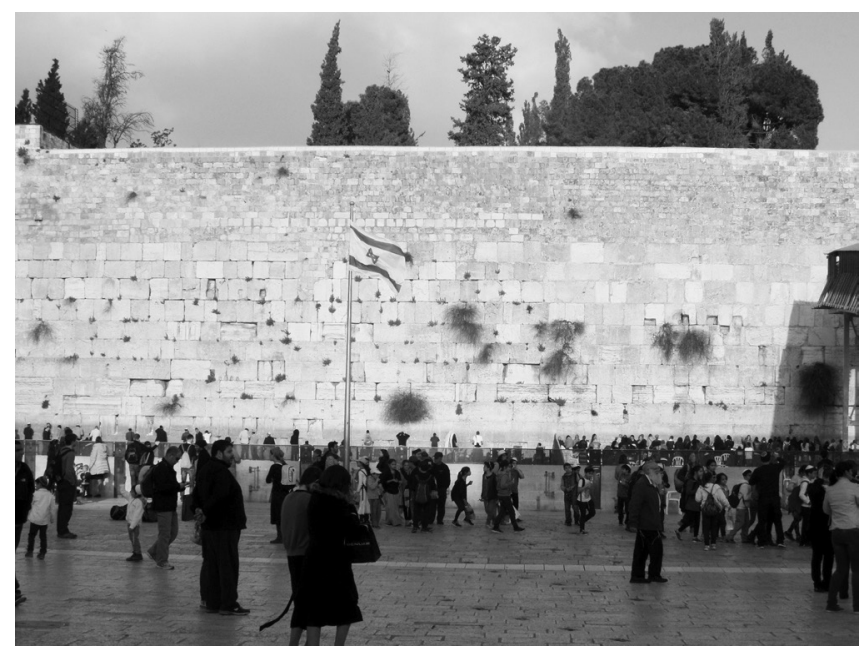

FIgURE 40. Western Wall. Photo by Katharina Galor.

first raised by Baron Rothschild in 1887 , a plan that was only executed in $1967 . .^{51}$ In contrast to the minor attention that the neighborhood adjacent to the wall received from residents, visitors, and scholars of ancient Jerusalem, an area which housed buildings ranging in date from the early Ayyubid period through the late Ottoman period, including houses of worship, the wall itself started to absorb the concern and care of the local communities and professionals as early as the beginning of the twentieth century. In 1920, Muslim authorities began conducting minor repairs to the Western Wall's upper courses. Though the Jewish community agreed that the work was necessary, they appealed to the British authorities, requesting that the conservation initiatives be carried out under the supervision of the newly established Department of Antiquities, recognizing the wall as part of a historic monument requiring specialized treatment..$^{52} \mathrm{~A}$ decision was then taken to place the maintenance of the small, upper stone courses under the authority of the Supreme Muslim Council (SMC), while the lower Herodian and Umayyad masonry was to be preserved by the Department of Antiquities, a decision challenged by the Mufti of Jerusalem. This partition of responsibilities was reiterated a number of times but has rarely proved itself as a viable means to adequately solve conservation problems..$^{53}$

For Jews, the Temple Mount marks the site of the destroyed First and Second Temples. Despite the fact that the city's early Muslim conquerors and the builders of the Dome of the Rock intended to mark the exact spot of the former Jewish Temple, in recent decades, the Temple's existence has been contested in the Muslim world, a view that is fed by the threat presented by Israel's sovereignty over 
Islam's third holiest place. For Israelis, the reclaiming of the Temple Mount in 1967 goes far beyond recovering the physical structure. It represents the reclaiming of Judaism's holiest site, which, according to the biblical narrative, came into being some 1,600 years before Islam was born. It is the Jewish antecedence to Islam, visually and physically encapsulated at this very location, that is regarded by Israelis as the ultimate proof for their right to resettle the land, to occupy East Jerusalem, and to reclaim the monument some two thousand years after the destruction of the Temple. And it is those very consequences, rather than the facts in isolation, which Palestinian Muslims consider a threat to their entitlement of continued worship and ownership. Therefore, a common statement within various Palestinian educational and media fora, is that the existence of a Jewish Temple is an ideologically motivated myth rather than a historical fact. This belief has found resonance even within scholarly circles, exemplified by Palestinian-Jordanian historian Kamil al'Asali's statement that "modern archaeology has not succeeded in proving that the site on which the Temple stood is located in this place, since no remnants of the Temple have survived." 54 Though more accepting of the chronologies of Jewish temples and Muslim shrines, but certainly no less radical ideologically, is the argument among some Jewish fringe groups that the Jewish Temple should be restored. This vision, which would necessarily involve the destruction of the Dome of the Rock, has been advocated by the Temple Mount Faithful movement as well as other organizations established in recent decades. ${ }^{55}$ This idea, though it comes from a radical element of Israeli society, has led to both preemptive and responsive actions among Palestinian Muslims, escalating the general atmosphere of mistrust and adversarial engagement, frequently involving violence on both sides.

In an effort to counter Israel's somewhat disguised efforts to solidify their political and military control of the Haram through archaeological excavations, Muslim leaders and the Arab media have repeatedly claimed that Israeli archaeologists are digging tunnels underneath the Haram to undermine the stability of the compound and destroy the al-Aqsa Mosque. ${ }^{56}$ It is indeed the case that in recent decades there are cracks and bulges noticeable along the southern and western enclosure walls as well as damage in buildings situated above the Western Wall Tunnels. It should be stated, however, that even if the excavations abut directly the enclosure wall or platform, they do not extend underneath. Furthermore, all work is performed with extreme caution, using sophisticated reinforcement and support systems made of steel and concrete. The primary interest, beyond doubt, is to expose and emphasize elements associated with the Jewish Temples. But the physical destruction of the Haram would also cause the obstruction of Judaism's holiest site, making the destruction of the Haram a rather implausible motivation. Though excavations conducted adjacent to the Haram and underneath nearby buildings may have impacted their stability, it is impossible to assess to what extent the structural damages have been caused by the archaeological activity. The many 
centuries of use and wear, the often inadequate restoration measures employed in those buildings, and the repeated earthquakes are all contributing factors that have to be taken into account.

A further claim that affects the site's cultural heritage and the way it is perceived by various communities concerns recent construction and maintenance work undertaken on top of the Haram platform. The construction of the Marwani Mosque between 1996 and 1999, as well as electrical cable replacements in 2007, were condemned by the Temple Mount Sifting Project as efforts to obliterate traces of the First and Second Jewish Temples. ${ }^{57}$ Though both the Islamic Movement in Israel and the Waqf are indeed concerned exclusively with the Islamic heritage of the site, these recent works only marginally affected archaeological remains from periods associated with the Jewish Temples..$^{58}$ Most of the material removed during the course of the Marwani Mosque construction and the cable work was debris and fill material from the Ayyubid and later periods, affecting — if at all—the Islamic layers and heritage of the site. ${ }^{59}$ Given the highly questionable scientific contribution of the Sifting Project, the only significance of the endeavor is of a political nature, by calling attention to the negligence in which the Waqf recently carried out the work on the Haram.

Whether it is primarily the excessive nature of the archaeological work conducted near the enclosure wall conducted by Israelis or rather the inadequate enforcement of archaeological supervision during repair or construction initiatives by Palestinians does not really matter. In the end, it is the lack of coordination, along with the religious, ideological, and political differences of the various sides involved in the administration and execution of these endeavors, that is at the core of the compound's inadequate state of preservation. Rather than investing in the exposure and excavation of hidden elements, professionals and researchers should focus on the maintenance and study of the exposed and accessible areas, which, other than the Dome of the Rock, the al-Aqsa Mosque, and the enclosure wall, include hundreds of buildings and artifacts spanning more than two thousand years of history. Such a change in course of action, which would not only benefit all of the involved communities but also the monument itself, is, however, unthinkable in the context of Israel's occupation of East Jerusalem. 